\title{
The Effect Of Modified Domino Cards Game On Students' Vocabulary Mastery
}

\author{
${ }^{1}$ Muhamad suhaili, ${ }^{2}$ K. Dedy sandiarsa \\ ${ }^{12}$ English Student, FBMB, UNDIKMA, Indonesia \\ 1suhailimuhamad46@gmail.com, dedysandiarsa36@gmail.com
}

\begin{abstract}
This research aimed to find out the effect of modified domino cards game on students' vocabulary mastery at the seventh grade students of Mts Negeri 3 Mataram in academic year 2019/2020. The research was pre experimental design. The population of the study was the seventh grade students that consisted of five classes. The sample of the study was class VII C that consists of 39 students. The class was treated using modified domino cards game. The result of the study shows that there is significance positive effect of modified domino cards game on students' vocabulary mastery. The data of the research were gathered from data analysis and inferential analysis. In data analysis, the mean score of pre test was 44.62 and post test was 73 ; the mode score of pre-test was 45.9 and post test was 78.3; the median score of pre-test was 44.8 and post test was 78.14; the score of standard deviation on both of the test was 11.27. In inferential analysis, the result showed that the value of t-test (18.94) was higher than the value of t-table (2.024) with significance level of $5 \%$. The finding of this study led into the conclusion that the use of modified domino cards game shows positive effect on students' vocabulary mastery at the seventh grade of Mts Negeri 3 Mataram. This is based on the t-test > t-table $(18.944>2.024)$ in degree significant of 5\%. It means that Ha was accepted and Ho was rejected. Therefore, it can be concluded that modified domino cards game gives positive effect on students' vocabulary mastery at the seventh grade students of MTs Negeri 3 Mataram in academic year 2019/2020.
\end{abstract}

Keywords: Modified Domino Cards Game, Vocabulary Mastery,

\section{INTRODUCTION}

Vocabulary is one of the sub skill that is very important in learning English because it is one of the requirements for people to use language to communicate. The students who have sufficient vocabulary, it will be easy for them to understand and comprehends English. According to Read (2000) vocabulary is knowledge of knowing the meaning of words they are elements that are combined to make an accurate choice, so it will effectively convey thought and ideas. Unfortunately, many students consider learning vocabulary as a tedious job. Teaching vocabulary in a foreign language classroom is not easy. It is not enough for English teacher to only prepare their students to use list of words and ask them to memorize the words. They are expected to provide students with exciting exercises which can help them to prepare and improv their motivation to learn vocabulary.

Thornburry (2002: 13) states that without vocabulary nothing can be conveyed. It means that learning vocabulary is very important because vocabulary is the most important thing that must be learned before others. By mastering vocabulary, the students will master the language skill such us: speaking, reading, listening, and writing because mastery of vocabulary will be very helpful when the students learn foreign language. It might be hard to do master the four skills if they do not know vocabulary.

The result of observing at MTs Negeri 3 Mataram in the academic year 2019/2020 showed that students are difficulties to know the meaning of the word, they had low vocabulary mastery and they do not even know the English words for things in the classroom. The students seemed not to have high curiosity to learn English words that are presented by the teacher. This problem may happen because the students seemed not to learn English words that are really interesting in English lesson or the way the teacher teaches was unattractive. The class activities had a heavy dependence on textbook, so that the lesson did not run effectively and resulting 
in a condition where all students got bored with the lesson unmotivated to learn.

In developing students' vocabulary, the researchers should use a suitable teaching strategy. In this research, the researchers offered a strategy to solve students' problems, especially in vocabulary mastery. There are many kinds of teaching strategies; the researchers are interested to employ Modified Domino Cards Game in order to increase students' vocabulary. Domino Cards game was utilized as a game which use cards as the media made of any particular paper content of a word of target language. On one side is picture and on the other side is the meaning of the picture in English. According to Lebedova (2011: 20), dominoes are very useful, easy, and entertaining game to practice any set of vocabulary. The researcher makes the Domino Cards game simple to make the students active and engaged their learning. In teaching and learning process this game can be practiced by asking students to recall words they have learned after the lesson. This game is easy to be played because it helps students memorize the words. The teacher will let students make some efforts in order to solve the problem given. When students are actively involved in problem solving process, students will memorize the new words deeply and be able to recall them easily instead of the teacher telling the students some new words.

According to Lebedova in Rahmawati (2017) designed the modified domino cards game in teaching vocabulary, the procedures are as follows: (1) The teacher gives the instruction on how to play the game and explains the rule in playing the game. (2) The teacher divides the students into 5 groups, one group consist of 8 students. (3) The teacher gives one set Dominoes that consist of 40 cards to each group. (4) The teacher asks each group to shuffle/mix up the Dominoes and the group leader distributes 5 cards to each member. (5) Each member of the group matched each picture with the meaning in the domino cards. (6) The winner is the group that can finish arranging Dominoes faster than the other groups. (7) The teacher asks to each the students to memorize all of the vocabulary in domino cards. The researchers use Domino
Cards in teaching English because it has many advantages in teaching for the students in class.

According to Vuano and Ciolino in Rahmawati (2017) dominoes have many advantages, those are: It creates enjoyable situation, it automatically stimulates students' interest, it makes students to focus on a specific structure, it is as reinforcement for the students to contribute to an atmosphere of healthy competition and ensure a great amount of student participation, and it makes the teachers usually get immediate feedback by using these kinds of activities. Seeing the advantages of modified domino cards game, students think that this technique is very useful for them so that the perception of students is positive.

\section{RESEARCH METHOD Research Design}

This study applied pre experimental research design. It meant there was only one class as the sample of the research that was experimental group without control group. The reason that the researcher used preexperimental research design because this study was intended to know the effect of modified domino cards game on students' vocabulary mastery at seventh grade of MTs Negeri 3 Mataram by comparing between the students' scores before they are being taught by using modified domino cards game and after they are being taught by using modified domino card game. That is why in this study the researcher just takes one group and use pre-test and post-test to see the result of the treatment. In this case, the researcher used One-Group Pretest-Posttest Design. The researcher gave pre-test to the students and then given the treatment or taught the students by using Modified Domino Cards Game. After that, the researcher gave post-test to the students.

\section{Population and Sample}

According to Sugiyono (2017: 117) population is generalisation region that consist of objects or subjects who have certain qualities and characteristics defined by researcher to learn and then draw the conclusion. In this study, the population was the seventh grade students of MTs Negeri 3 
Mataram in the academic year 2019/2020 which consist of 5 classes. Where VIIA consist of 40 students, VII B is 40 students, VII C is 39 students, VII D is 38 students and VII D is 39 students. The total number of students was 196 students.

Based on the total number of population, the researcher took one classes as the sample of this research. To determine the sample of this research, the researcher used simple random sampling technique; it is form to got some participants randomly based on the population because all of the population are used. From the sampling technique, the sample of this research was students from VII $\mathrm{C}$ that consists of 39 students. The researchers took VII C because based on the information and suggestion from English teacher, the condition of the class was passive when teaching learning English and they had low vocabulary mastery than the other class. So, this class was appropriate to be given a treatment.

\section{Research Instrument}

Research instrument is the tool that is used to measure the nature or social phenomenon that is being researched Sugiyono (2017: 148). The researcher was used vocabulary test in the form of multiplechoice that consists of 20 questions with 4 options (a, b, c, or d).

\section{Data Analysis}

According to Sugiyono (2017: 308) Technique of data collection is the major step in this research, because the major purpose of the research is to obtain data. It meant technique of data analysis is the way to collect any information or the data from the student, to support the researcher to get much information. The techniques of data collection that the researcher used are: (1) Pre-test is the first step of collecting the data. At the first meeting, the researcher gave the pre-test for the students. This pre-test aimed to know the ability of the students' vocabulary mastery before giving the treatment. (2) The post-test is the second step of collecting data in this research. This step was conducted after given the treatment. This test was given to find out the result of the students' vocabulary mastery after given the treatment.
The technique of data analysis is the way used by the researcher in analyzing the data that has been collected. In this research, the research was used descriptive analysis to display the important features of the data. The most commonly used measures of central tendency are mean, median, mode, and standard deviation. Meanwhile, inferential analysis is making conclusion in generally about the data that have been arranged or processed. The aimed of it was to answer or examine the hypothesis, weather it was accepted or rejected.

To identify whether there is an effect or not of Modified Domino Cards Game toward students' vocabulary mastery, the research compared the result of the t-test and t-table. If the $\mathrm{t}$-test $\geq \mathrm{t}$-table, the alternative hypothesis would be accepted. It means that Modified Domino Cards Game have positive effect toward students in vocabulary mastery. If the $\mathrm{t}$-test $\leq \mathrm{t}$-table, the null hypothesis would be rejected. It means that Modified Domino Cards Game have no positive effect toward students in vocabulary mastery.

\section{RESEARCH FINDINGS AND DISCUSSION}

\section{Research Findings}

This part was the description of the result of the pre-test before teaching by using Modified Domino Cards Game. The result of the data analysis showed the highest score was 75 and the lowest score was 15 , the mean score was 44.62 , the mode score was 46 , the median score was 44.8 and the standard deviation was 11.27. The following data frequency of distribution which was created based on steps of data analysis.

Table 1

\section{Frequency Distribution of Pre-test}

\begin{tabular}{|c|c|c|c|c|c|c|}
\hline No. & $\begin{array}{c}\text { Class } \\
\text { Limits }\end{array}$ & $\begin{array}{c}\text { Class } \\
\text { Boundaries }\end{array}$ & Midpoint & Tally & Frequency & Percentage \\
\hline 1 & $15-24$ & $14.5-24.5$ & 19.5 & II & 2 & $5 \%$ \\
\hline 2 & $25-34$ & $24.5-34.5$ & 29.5 & III & 4 & $10 \%$ \\
\hline 3 & $35-44$ & $34.5-44.5$ & 39.5 & III III III & 13 & $33 \%$ \\
\hline 4 & $45-54$ & $44.5-54.5$ & 49.5 & III III III & 15 & $38 \%$ \\
\hline 5 & $55-64$ & $54.5-64.5$ & 59.5 & III & 3 & $8 \%$ \\
\hline 6 & $65-74$ & $64.5-74.5$ & 69.5 & I & 1 & $3 \%$ \\
\hline 7 & $75-84$ & $74.5-84.5$ & 79.5 & I & 1 & $3 \%$ \\
\hline \multicolumn{7}{|c|}{ Total } \\
\hline
\end{tabular}


score was 50 , the mean score was 73 , the mode score was 78.3 , the median score was 78.14 and the standard deviation was 11.27. The frequency distribution and bar chart of the data were shown in table and graphic below:

\section{Histogram and Polygon of Pre-Test}

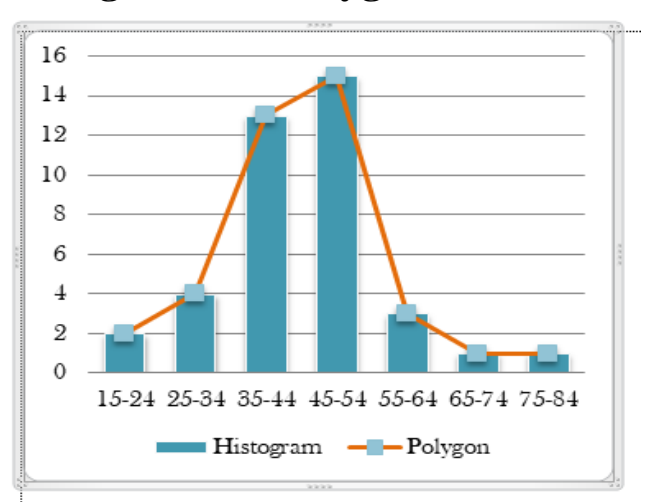

Based on the histogram and polygon above, it is shown that the frequency of students who got the score between 15-24 were 2 students, the students who got the score between 25-34 were 4 students, the students who got the score between 35-44 were 13 students, the students who got the score between 45-54 were 15 students, the students who got the score between 55-64 were 3 students, the students who got the score between 65-74 was 1 student and the last frequency of students who got the score between 75-84 was 1 student. This section contains the results of research and analysis done with an emphasis on the answer to the problems.

Table 2

\section{Frequency Distribution of Post Test}

\begin{tabular}{|c|c|c|c|c|c|c|}
\hline No. & $\begin{array}{c}\text { Class } \\
\text { Limits }\end{array}$ & $\begin{array}{c}\text { Class } \\
\text { Boundaries }\end{array}$ & Midpoint & Tally & Frequency & Percentage \\
\hline 1 & $50-57$ & $45.5-57.5$ & 53.5 & II & 2 & $5 \%$ \\
\hline 2 & $58-65$ & $57.5-65.5$ & 24.5 & 业 & 5 & $13 \%$ \\
\hline 3 & $66-73$ & $65.5-73.5$ & 69.5 & II & 2 & $5 \%$ \\
\hline 4 & $74-81$ & $73.5-81.5$ & 77.5 & IIII IIII III III & 18 & $46 \%$ \\
\hline 5 & 82.89 & $81.5-89.5$ & 85.5 & 刺 I & 6 & $15 \%$ \\
\hline 6 & $90-97$ & $89.5-97.5$ & 93.5 & 业 & 5 & $13 \%$ \\
\hline 7 & $98-105$ & $97.5-105.5$ & 101.5 & I & 1 & $3 \%$ \\
\hline \multicolumn{5}{|c|}{ Total } & 39 & $100 \%$ \\
\hline
\end{tabular}

In order to know students' score after the treatment, the researcher gave post-test, then the researcher got the score of the posttest after that the researcher calculated it by using descriptive analysis. Furthermore, the result of the analysis showed that the highest score of the post-test was 100 and the lowest

\section{Graphic 2}

Histogram and Polygon of Post Test

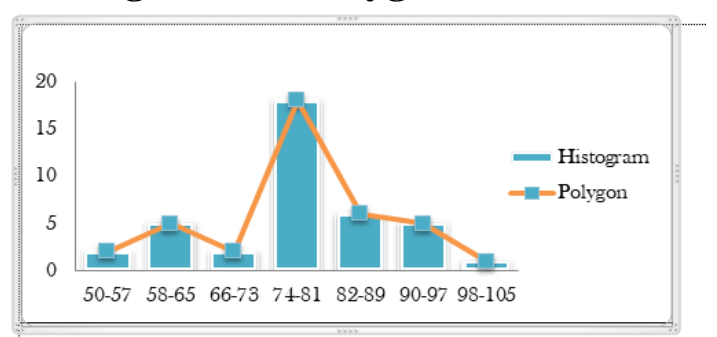

Based on the histogram and polygon of post test above, it is shown that the frequency of students who got the score between 50-57 were 2 students, the students who got the score between 58-65 were 5 students. The students who got the score between 66-73 were 2 students. The students who got the score between 74-81 were 18 students. The students who got the score between 82-89 were 6 students. The students who got the score between 90-97 were 5 students and the last frequency of students who got the score between 98-100 was 1 student.

At the end, the result of the testing hypothesis in the t-test formula shows that $\mathrm{t}$ test was 18.944 and the t-table was 2.024 with significance level 0,05 and the degree of freedom 38. Therefore, the score of t-test was higher than t-table $(18.944>2.024)$. It can be concluded that Null hypothesis (Ho) which state: "There is no positive effect of Modified Domino Cards Game on students' vocabulary mastery at the seventh grade students of MTs Negeri 3 Mataram in academic year 2019/2020" was rejected. Therefore, the Alternative Hypothesis (Ha) which states: "There is positive effect of Modified Domino Cards Game on students' vocabulary mastery at the seventh grade students of MTs Negeri 3 Mataram in academic year 2019/2020" was accepted.

After computing the result of the data in this research, it was found that Modified Domino Cards Game has positive effect on 
students' vocabulary mastery. It showed that the mean score of post test was 73 and the mean score of pre test was $44.62(73 \geq 44.62)$. This indicates that the hypothesis is accepted. It means that use modified domino cards game can increase students' vocabulary mastery. It can be concludes that there was any significant positive effect of the students in vocabulary before and after they were taught by using Modified Domino Cards Game.

\section{Discussion}

This research was designed to know the effect of modified domino cards game on students' vocabulary mastery at the seventh grade students of MTs Negeri 3 Mataram in the academic year 2019/2020. The researcher conducted some steps to reach the objectives of the research. The researcher used test as instrument of the research to get the data. The researcher did some steps; there were pre-test, giving treatment, and post-test.

Base on the data finding from the test, it showed that modified domino cards game gave a positive effect towards students' vocabulary mastery. There were some reasons why modified domino cards game could improve students' vocabulary mastery: First, the students looked interest and easily understand the material; second, by using domino card, the students were interested in joining the teaching learning process. So the score of the students after being taught by using modified domino card game was increase. It was in line with Rahmawati (2017) states that modified domino cards game is effective in teaching vocabulary. Besides, Hadfield (2001: 6) states "The idea of a game is probably easier for students to grasp from seeing the cards than from a verbal explanation". The students understand the material easily if the teacher conveys the material by using a card.

In teaching vocabulary, game can be used to teach in increasing vocabulary mastery of the students like Modified Domino Cards Game. According Baker and Wetrup (2000: 38), Domino cards here meant matching words and picture, or matching word to their meaning. This game was very useful, easy, and entertaining game to practice a set of vocabulary. It was line with the research by Sungkono (2016) who informs that modified domino cards game could make the students pay attention to the lesson properly; it also improved students' participation in learning vocabulary. Using this media, the students are able to see the picture on domino cards, the students can match the words and pictures or match words to their meaning. The students imagine that pictures what they saw. As a result, they can be easier to understand and memorized the vocabulary.

Base on the data obtained, the result showed that the score of post test was higher than the score of pre test, it meant that teaching English word by using Modified Domino Cards Game was effective in increasing vocabulary mastery. It can be conclude that there was any significant positive effect of modified domino cards game on students' vocabulary mastery at the seventh grade students of MTs Negeri 3 Mataram in academic year 2019/2020.

\section{CONCLUSION}

Base on the result of the statistical computation, the researcher found that result of t-test was 18.944 and t-table was 2.024. It is clear that the score of $\mathrm{t}$ - test was higher than t-table. So, the alternative hypothesis was accepted and the null hypothesis was rejected. It means that there is significance positive effect of modified domino cards game on students' vocabulary mastery.

Furthermore, the result of descriptive statistic of computation show the mean score of pre test was 44.62 and the mean score of post test was $73.0(73.0>44.62)$. This indicates that the hypothesis is accepted. It means that use modified domino cards game can increase students' vocabulary mastery. It can be concludes that there was any significant positive effect of the students in vocabulary before and after they were taught by using Modified Domino Cards Game.

In conclusion, teaching vocabulary by using Modified Domino Cards Game was effective and could be applied to teach vocabulary on the students at the seventh grade of MTs Negeri 3 Mataram 


\section{REFERENCES}

Lebedova, Martina. 2011. Practicing Vocabulary through game based activities. Masaryk University.

Imran, F., \& Hidayatullah, H. 2020. EFL Critical Reading Syllabus and Materials for Students of the English Department. JOLLT Journal of Languages and Language Teaching, 7 (1), 51-56. https:// doi:10.33394/joelt.v7i1.2747

Putri, Indah Rahmawati Pradiatama. 2017. The Effectiveness of using Modified Domino Card Game toward Students' Vocabulary Mastery. English Educational Department. Faculty of Tarbiyah and Teacher Training.

Read, John. 2000. Assessing Vocabulary. Cambridge: Cambridge University Press.

Sugiyono. 2017. Statistika Untuk Penelitan. Bandung: Alpabeta Bandung.

Thornbury, S. 2002. How to Teach Vocabulary. London: Longman Group

Westrup, Heather \& Baker, Joana. 2000. The English Language Teacher's Handbook. London: Continuum. 